\title{
An Archaeological Proposal of the Origin of State in China
}

\author{
Xu Hong 許宏 \\ Researcher of Institute of Archaeology, Chinese Academy of Social Sciences, \\ China \\ erlitou@sina.com
}

Translated by Zhang Yin

\begin{abstract}
The abundance of classical literature and the conventions of historical studies have shaped the archaeological exploration of the origin of the state in China, starting with and centering on the identification of specific dynasties. The linear evolutionary account of the Chinese civilization, based on royal genealogies, has become mainstream. The emergence of the state has been continuously dated earlier. I argue that theoretical flaws, nationalism, and disciplinary limits have obscured the complexities of this research project. Drawing on archaeological findings, I propose a two-stage model regarding the origin of the state in East Asia.
\end{abstract}

\section{Keywords}

academic history - Chinese archaeology - early China - nationalism - study of the origin of state

In the Chinese archaeological world, the concept of civilization is used not as a synonym of culture but as a term to designate a specific stage of social development. As Engels claims, "the state is the sum of the civilized society."1

1 Friedrich Engels 恩格斯, “Jiating, siyouzhi he guojia de qiyuan 家庭, 私有制和國家的起 源 [The Origin of the Family, Private Property and the State]," in Makesi Engesi xuanji 馬克 思恩格斯選集 [Marx and Engels Collected Works] (Beijing: Renmin chubanshe, 1995), 4: 172. 
The emergence of the state symbolizes that society has reached the stage of civilization.

The major strategy used in studying the origin of the state and the history of early Chinese civilization over the past hundred years is to make inferences from well-known characteristics of a mature civilization to the possible origin and formation of an early state. This strategy, coupled with an abundance of classical literature and historical knowledge, has made identifying specific dynasties the starting point and the central focus. In this article I draw from modern archaeology to enhance this research project.

\section{Overview: From “Confirming the Classics and Complementing History" to a Linear Evolutionary Account}

\section{1 \\ From the 1920 s to the Present: the Practice of "Confirming the Classics and Complementing History" and Royal Genealogies}

In the early twentieth century, Wang Guowei 王國維 [1877-1927] deciphered the oracle bone scripts unearthed from the Yinxu 殷墟 [Ruins of Yin] in Anyang. These earliest Chinese writings have verified the lineage tables of YinShang emperors and the events recorded in the "Basic Annals of Yin" [Yin benji 殷本紀] in the Records of the Grand Historian [Shiji 史記]. ${ }^{2}$ This breakthrough encouraged historians and archaeologists to validate the "Basic Annals of Xia" [Xia benji 夏本紀] in the Records of the Grand Historian and descriptions of the Xia dynasty in the pre-Qin literature and to agree upon the existence of the Xia dynasty (ca. 2100-1600 BCE). This mode of inference has been widely accepted and highlights the role archaeological findings can play in "confirming the classics and complementing history." 3

The excavation of the Yinxu in Anyang since 1928 has further verified the area as the capital of the late Shang dynasty (ca. 1600-1046 BCE). ${ }^{4}$ With the excavation of Erligang 二里崗 culture and the Zhengzhou 鄭州 Shang city

2 Wang Guowei 王國維, “Yin buci zhong suojian xiangong xianwang kao 殷卜辭中所見 先公先王考 [Study of the Ancestral Kings and Nobility Appearing in the Yin Oracular Inscriptions]," Guantang jilin 觀堂集林 [Guantang's Selected Works], part I, vol. 9 (Beijing: Zhonghua shuju, 1959); Wang Guowei, "Yin buci zhong suojian xiangong xianwang xukao 殷卜辭中所見先公先王續考 [The Second Study of the Ancestral Kings and Nobility Appearing in the Yin Oracular Inscriptions]," Guantang jilin, part I, vol. 9.

3 Xu Hong 許宏, "Fangfalun shijiao xia de Xia Shang fenjie yanjiu 方法論視角下的夏商分 界研究 [The Methodological Demarcation of Xia from Shang], in Sandai kaogu 三代考古 [Archaeology of Three Dynasties] (Beijing: Kexue chubanshe, 2009).

$4 \mathrm{Li} \mathrm{Ji}$ 李濟, Anyang-Yinshang gudu faxian fajue fuyuan ji 安陽一殷商古都發現、發掘、 復原記 [Anyang: A Chronicle of the Discovery, Excavation, and Reconstruction of the Ancient 
(culturally close to Yinxu) in the 1950s, the Shang dynasty was dated back to the period of Erligang. ${ }^{5}$ In 1959, Xu Xusheng 徐旭生 [1888-1976] excavated the ruins of Erlitou 二里頭 in the exploration of possible "Ruins of Xia" [Xiaxu 夏墟]." ${ }^{\prime}$ The lack of archaeological materials at this point has limited archaeologists to the imagination of Xia culture and the general demarcation of the Xia dynasty from the Zhou dynasty [1046-256 BCE]. The limited archaeologicalmaterials were later used to serve integrative historical research. ${ }^{7}$ Experts in the XiaShang-Zhou Chronology Project, which was initiated in the 1990s, relied mostly on the classical literature as their argumentative basis. ${ }^{8}$ Scholars wrote that the concept of theXia was still an assumption yet to be corroborated. Archaeological fieldwork was limited to the Yellow River Basin until the 1970s. Consequently, Chinese archaeologists mostly held a Zhongyuan-centric model that upholds a monist origin of Chinese dynasties, regarding the Shang or Xia dynasty as the earliest state.

\section{From the 1970 s to the Present: the Linear Evolutionary Account as} Mainstream, with the Upper Limit Continuously Shifted Earlier Several models have been proposed to account for the concept of the civilization and the origin of the state in China. Other than the Zhongyuan-centric model [xinzhongyuan zhongxin shuo 心中原中心說], ${ }^{9}$ we have seen the "starry

Capital of the Shang Dynasty], trans. Su Xiuju 蘇秀菊 et al. (Beijing: Zhongguo shehui kexue chubanshe, 1990).

5 Zou Heng 鄒衡, “Shi lun Zhengzhou xin faxian de Yin Shang wenhua yizhi 試論鄭州新發 現的殷商文化遺址 [The New Discovery of Yin-Shang Cultural Site in Zhengzhou]," Kaogu xuebao 考古學報, no. 3 (1956); Henan sheng bowuguan 河南省博物館, Zhengzhou shi bowuguan 鄭州市博物館, “Zhengzhou Shangdai cheng yizhi fajue baogao 鄭州商代城遺 址發掘報告 [Excavation Report of Shang Relics in Zhengzhou]," in Wenwu ziliao congkan 文物資料叢刊, vol. 1 (Beijing: Wenwu chubanshe, 1977).

6 Xu Xusheng 徐旭生, “1959 nian xia Yuxi diaocha Xiaxu de chubu baogao 1959 年夏豫西 調查“夏墟'的初步報告 [Preliminary Report of the Investigations into 'Xiaxu' in Western Henan in the Summer of 1959]," Kaogu 考古, no. 11 (1959).

7 Henan sheng kaogu xuehui 河南省考古學會, Henan sheng bowuguan 河南省博物館, Xia wenhua lunwen xuanji 夏文化論文選集 [Selected Papers on the Xia Culture] (Zhengzhou: Zhongzhou guji chubanshe, 1985); Zhongguo xianqin shi xuehui 中國先秦史學會, ed., Xia shi luncong 夏史論叢 [Collected Essays on the History of Xia] (Jinan: Qilu shushe, 1985); Zheng Jiexiang 鄭傑祥, ed., Xia wenhua lunji 夏文化論集 [An Anthology of the Xia Culture] (Beijing: Wenwu chubanshe, 2002).

8 Xia-Shang-Zhou duandai gongcheng zhuanjia zu 夏商周斷代工程專家組, Xia-ShangZhou duandai gongcheng 1996-20oo nian jieduan chengguo baogao jianben 夏商周斷代工程 1996-2000 年階段成果報告（簡本）[The Xia-Shang-Zhou Chronology Project Report for the years 1996-200o (abridged)] (Beijing: Shijie tushu chuban gongsi, 2000).

9 An Zhimin 安志敏, “Shi lun Huanghe liuyv xin shiqi shidai wenhua 試論黃河流域新石 器時代文化 [Neolithic Culture in the Yellow River Basin]," Archaeology, no. 10 (1959); Shi 
sky model [mantian xingdou shuo 滿天星斗說],"10 the model of mutually influencing circles [zhongguo xianghu zuoyongquan shuo 中國互相作用圈說],11 the Zhongyuan-centric model of double flowers [chongban huaduo shuo 重瓣花朵說] (otherwise known as the model of unity through plural societies) [duoyuan yiti shuo 多元一體說], ${ }^{12}$ the Zhongyuan-centric model of historical trend [lishi qushi shuo 歷史趨勢說],13 and the neo-Zhongyuan-centric model [xin zhongyuan zhongxin shuo 新中原中心說 $],{ }^{14}$ and so on.

All these alternative models can still be interpreted as variations of the Zhongyuan-centric model, albeit from a pluralistic perspective. The underlying tenet remains unchanged: all the pre-historical local cultures are relatively independent but intimately connected, each evolving without interruption, before merging into a single entity conceived of as Chinese civilization. Despite a general acknowledgment of inequities and imbalances in social developments, a striking silence loomed over the disparities and distances among different regions and cultures. Consequently, the heterogeneity within different regions and cultures in antiquity has been significantly downplayed, fostering a mentality that privileges a linear evolutionary account of Chinese civilization. This mentality has generated grand narratives of the origin and formation of Chinese prehistoric culture, which tackles historical periods with generic

Xingbang 石興邦, “Huanghe liuyu yuanshi shehui kaogu yanjiu shang de ruogan wenti 黃河流域原始社會考古研究上的若干問題 [Archaeological Problems of Primitive Societies in the Yellow River Basin]," Kaogu, no. 10 (1959).

10 Su Bingqi 蘇秉琦 and Yin Weizhang 殷瑋璋, “Guanyu kaogu wenhua de quxi leixing wenti 關於考古學文化的區系類型問題 [Archaeological Culture: Region, System, Class]," Wenwu 文物, no. 5 (1981).

11 Kwang-chih Chang, The Archaeology of Ancient China, 4th ed. (New Haven:Yale University Press, 1986). For an early Chinese translation, see Kwang-chih Chang 張光直, “Zhongguo xianghu zuoyongquan yu wenming de xingcheng 中國相互作用圈與文明的形成 [The Mutually Influencing Circles and the Formation of Civilization]," in Qingzhu Su Bingqi kaogu wushiwunian lunwenji 慶祝蘇秉琦考古五十五年論文集 [A Collection of Essays in Celebration of Su Bingqi's 55-year Archaeological Work] (Beijing: Wenwu chubanshe, 1989).

12 Yan Wenming 嚴文明, “Zhongguo shiqian wenhua de tongyixing yu duoyangxing 中國 史前文化的統一性與多樣性 [The Unity and Diversity in Chinese Prehistoric Culture]," Wen $W u$, no. 3 (1987).

13 Zhao Hui 趙輝, “Yi Zhongyuan wei zhongxin de lishi qushi de xingcheng 以中原為中 心的歷史趨勢的形成 [The Formation of the Zhongyuan-Centric Historical Trend]," Wen Wu, no. 1 (2000); Zhao Hui, "Zhongguo de shiqian jichu—zai lun yi Zhongyuan wei zhongxin de lishi qushi 中國的史前基礎一再論以中原為中心的歷史趨勢 [The Prehistoric Foundation of China: Revisiting the Zhongyuan-Centric Historical Trend]," Wen Wu, no. 8 (2006).

14 Zhang Xuehai 張學海, “Xin Zhongyuan zhongxin lun 新中原中心論 [Neo-ZhongyuanCentrism]," Zhongyuan wenwu 中原文物, no. 3 (2002). 
labels such as "the late Neolithic" or the Chalcolithic. ${ }^{15}$ The predominant concern remains how to trace the origin of a single Zhongyuan state, driven by the ideal of unity in contemporary China. Even Liangzhu 良渚 culture, which was located outside Zhongyuan and perished hundreds of years before the birth of Zhongyuan civilization, has been considered just an important component of the unfaltering development of Chinese civilization.

Even since the late 1970s, increasing archaeological findings have launched a reassessment of the ancient Chinese civilization with a focus on what is called the "proto-history" of the Xia era or even the "legendary time" of the five ancient emperors. Nonetheless, the extensiveness of the reassessment does not change the central question of how China emerged into the stage of civilization.

Drawing from research on the pottery scripts of Dawenkou 大汶口 culture, Tang Lan 唐蘭 [1901-1979] proposed in the 1970s that Chinese civilization spans over 6,00o years. ${ }^{16}$ Discoveries in the 1970 os and 1980 os seem to show that Liangzhu culture had private ownership, arrived at the eve of civilization, or even entered the era of the state. Meanwhile, discoveries of Longshan 龍山 culture ruins, such as the Wangchenggang 王城崗 ruins in Dengfeng 登封 county in Henan or the Taosi 陶寺 ruins in Xiangfen 裏汾 county in Shanxi, cohered with legends of the Xia dynasty or countries in the era of the five ancient emperors. China, by implication, entered a primitive stage of civilized society still earlier. ${ }^{17}$ Drawing on the discoveries made in Hongshan 紅山 culture in western Liaoning, Su Bingqi 蘇秉琦 (1909-1997) proposed in

15 Xu Hong, “Xin Zhongyuan zhongxin lun de xueshushi jiexi ‘新中原中心論'的學術史解 析 [An Analysis of the History of 'Neo-Zhongyuan-Centrism']," in Wuxian youyou yuanguqing一Tong Zhuchen xiansheng jinian wenji 無限悠悠遠古情一倐柱臣先生紀念文 集 [Collected Essays in Memory of Tong Zhuchen] (Beijing: Kexue chubanshe, 2014).

16 Tang Lan 唐蘭, "Zhongguo you liuqian duo nian de wenmingshi-Lun Dawenkou wenhua shi Shaohao wenhua 中國有六千多年的文明史一論大汶口文化是少吴 文化 [China Has Over 6,0oo Years of Civilized History: On How the Dawenkou Culture is Shaohao Culture]," in Dagongbao zai Gang fukan 30 zhounian jinian wenji 大公報在 港復刊 30 週年紀念文集 [Collected Papers for the 3oth Anniversary of the Resuming Publication of Ta Kung Pao] (Hong Kong: Dagongbao, 1978); Tang Lan, "Zhongguo nuli zhi shehui de shangxian yuan zai wu, liu qian nian qian-lun xin faxian de Dawenkou wenhua yu taoqi wenzi 中國奴隸制社會的上限遠在五、六千年前一論新發現的 大汶口文化與其陶器文字 [The Upper Limit of the Chinese Slavery Society Is 50006000 Years Ago: On the New Discovery of the Dawenkou Culture and Its Pottery Scripts]," in Dawenkou wenhua taolun wenji 大汶口文化討論文集 [Collected Essays on the Dawenkou Culture] (Jinan: Qilu shushe, 1981).

17 Zhongguo shehui kexueyuan kaogu yanjiusuo 中國社會科學院考古研究所, Zhongguo shehui kexueyuan gudai wenming yanjiu zhongxin 中國社會科學院古代文明研究中 心, ed., Zhongguo wenming qiyuan yanjiu yaolan 中國文明起源研究要覽 [A Survey of the Studies on the Origin of the Chinese Civilization] (Beijing: Wenwu chubanshe, 2003). 
the 1980 s that Hongshan culture inaugurated the period of "ancient states" in China. He further proposed the "starry sky model," according to which Chinese civilization consists of developmental stages that can be labeled "ancient culture, ancient city, ancient state" or "ancient states, regional states, and empire states." ${ }^{18}$ But it is an open question whether a massive religious phenomenon and public social project such as Hongshan culture can prove the existence of an authoritative state power. The proposal of 5,000-year Chinese civilization, as influenced by the Zhongyuan-oriented view, nationalism, and interpretive changes brought by archaeological finds, prioritizes the long tradition and broad cultural identification. Yet many questions are left unanswered if civilization is to be defined from the perspective of the emergence of the state. ${ }^{19}$

Reflection: Theoretical Flaws, Nationalism, and Disciplinary Limits

Archaeology in China has downplayed the significance of theory. "Special attention is given to the obtaining and confirming of archaeological materials. Trust is not given to theories, often seen as stereotyped views. To force subjective theories onto archaeological materials is not considered rigorous work."20 The theoretical work regarding the origin of the state is significantly lacking, which has directly affected the depth and quality of research. For example, Su Bingqi has defined an "ancient state" as "a higher form of social organization coming from yet going beyond community."21 This definition is widely thought to be unclear in its intension and extension. ${ }^{22}$ A publicly recognized discourse is hard to take shape, when disagreements abound regarding the most basic concepts and theoretical frameworks.

18 Su Bingqi, Huaren-Long de chuanren-Zhongguoren-Kaogu xungen ji 華人·龍的傳人. 中國人一考古尋根記 [Ethnic Chinese, Descendants of the Dragon, the Chinese People: In Search of an Archaeological Root] (Shenyang: Liaoning daxue chubanshe, 1994); Su Bingqi, Zhongguo wenming qiyuan xintan 中國文明起源新探 [A New Investigation into the Origin of the Chinese Civilization] (Shanghai: Sanlian shudian, 1999), 170.

19 Chen Xingcan 陳星燦, “Cong yiyuan dao duoyuan: Zhongguo wenming qiyuan yanjiu de xinlu licheng 從一元到多元: 中國文明起源研究的心路歷程 [From Monism to Pluralism: The Study of the Origin of the Chinese Civilization]," Zhongyuan Wenwu, no. 2 (2002).

$20 \quad$ Kwang-chih Chang, “Xuyan 序言 [Preface],” in Shijian yu chuantong 時間與傳統 [Time and Traditions: Essays in Archaeological Interpretation], by Bruce G. Trigger 布魯斯·炊格 爾, trans. Jiang Zudi 蔣祖棣, and Liu Ying 劉英(Shanghai: Sanlian shudian, 1991), 5.

21 Su Bingqi, Ethnic Chinese, Descendants of the Dragon, 81.

22 Zhu Naicheng 朱乃誠, Zhongguo wenming qiyuan yanjiu 中國文明起源研究 [A Study of the Origin of the Chinese Civilization] (Fuzhou: Fujian renmin chubanshe, 2006). 
The distinctive origin of the Chinese state has led many scholars to uphold the value of authenticity in historical literature. Although research on the origin of the state is a global project, Chinese and international scholars have had little communication and many barriers. It is not hard to notice the tendency to close the door and talk to oneself. Ill-defined concepts such as "ancient state," [guguo 古國] "regional state," [ fangguo 方國] and "kingdom-state" [bangguo 邦國] have not been well integrated with Western concepts such as "chiefdoms" [qiubang 酋邦] and “primitive states” [zaoqi guojia 早期國家]. The concept of a chiefdom, for example, denotes a pre-state complex social interim from the primitive egalitarian society to the state-society. This concept has not been widely accepted in Chinese academia, and most hold a two-tiered view that sharply contrasts the pre-state society with the state-society.

Chinese literature can be dated back between Eastern Zhou [770-256 вСЕ] and the Han dynasty [202 $\mathrm{BCE}-220]$, when state-society took a mature form. When ancient events in pre-state societies were characterized, the political regimes were variously called a "country" [bang 邦] or a "state" [guo 國]. Contemporary scholars tend to read these terms at face value and exaggerate their significance in an attempt to date and locate the origin of state. Meanwhile, the origin of the state has been continuously shifted to an earlier point to match early civilizations globally. Some scholars have even asserted with a clear tone of nationalism that "the aim of modern archaeology is to revise the history of the state."23

The origin of civilization or the state predates the era when literature containing abundant historical information about local regions came into existence. Archaeology plays an important role in the research on pre-history. With respect to the question of the origin of civilization and the state, however, archaeology can only go so far to reveal, record, and observe the material embodiment of civilization. The definition and analysis of the state involves institutional theorizing beyond the domain of archaeology. On the one hand, the archaeological remains are fragmented, even piecemeal. On the other hand, the lack of textual support worsens the intellectual uncertainties.

Archaeological work has a strong interpretive aspect, given its effort to study the past through material remains. The archaeological materials do not speak for themselves, whereas the interpretations given by the archaeologists will inevitably carry their opinionated preferences. Problems of conceptual compatibility might also arise when archaeologists borrow from theories and methodologies in other disciplines. We shall keep in mind the relativity and unverifiability of any conclusion regarding the origin of the state.

23 Su Bingqi, A New Investigation into the Origin of the Chinese Civilization, 4. 
To distinguish the geological sense from the political sense, I shall refrain from using the word "China" in articulating this proposal. Instead, I shall use "East Asia" as a spatial category. Between 3500 and 1800 BCE - between the Yangshao 仰韶 and Longshan eras-numerous regions in the Yellow River Basin and the Yangtze River Basin underwent profound social changes. Ancient tribes or clans, relatively independent, coexisted in a conflict and contest for resources. That period in East Asia has been metaphorically characterized as an era full of "stars." The sheer number of tribes or clans was so striking that scholars have called that period "the era of ancient kingdoms" or, borrowing from Western parlance, "the era of chiefdoms."

The increasing population in that period witnessed the growth of class stratification and social complication. As communication and clashes across different regions became frequent, unprecedented cultural phenomenon emerged. The forms of tribes underwent fundamental changes. Prominent disparities were manifest everywhere in the relics of major social projects that required much labor and time, such as the ramparts and ditches, rammed-earth foundation platform, hall buildings, altars, graves, not to mention the grave scale, and the quantity and quality of grave goods. Groups of ancient people formed loose circles of mutual influence through communication and clashes. Nevertheless, they were independent from one another and dispersed geologically. These local cultures on the periphery of Zhongyuan later headed toward decline and eventually exited the historical stage.

Around roughly $1800 \mathrm{BCE}$, the remaining cities and central tribes in Longshan culture in Zhongyuan disappeared one after another. Replacing them was Erlitou culture in Mount Song 嵩 and Luoyang 洛陽 in Zhongyuan, quickly absorbing the cultural elements from local regions before rising to prominence. For the first time in East Asia, Erlitou culture spread beyond local geological units, occupying almost the entire middle reach of Yellow River. Erlitou culture then radiated to surrounding areas much farther. The culture and cities of Erlitou emerged, merging the societies then into a large territory royal dynasty from the coexistence of separate political entities. The Yellow River Basin and the Yangtze River Basin slowly developed from a pluralistic civilization of separate tribes to an integrated civilization of royal dynasties. ${ }^{24}$

24 Xu Hong, Zuizao de Zhongguo 最早的中國 [The Earliest China] (Beijing: Kexue chubanshe, 2009); Xu Hong, Heyi Zhongguo-Gongyuan qian 2000 nian de Zhongyuan tujing 何以中國一西元前 2000 年的中原圖景 [Why Is It China: the Zhongyuan Landscape in 2000 BCE] (Shanghai: Sanlian shudian, 2014). 
I propose that Erlitou culture, the earliest large territory royal dynasty around 1800 BCE in East Asia, demarcated the era of the Zhongyuan dynasty from the predynastic era, when great numbers of smaller political entities coexisted. This demarcation happens to match neatly onto the boundary between the Bronze Age and the Pre-Bronze Age in East Asia. Consequently, the origin of the states in East Asia exhibited discontinuity and disproportion. A number of ancient cultures, represented by Liangzhu, Shimao 石峁, and Taosi, completed the rise and fall of their developments. The bronze civilization in Zhongyuan after these earlier cultures had an indirect relationship to them, thus showcasing cultural fracture within continuity. ${ }^{25}$ For example, the sorcery-filled Liangzhu culture perished early and exhibited remarkable differences in cultural identity from Zhongyuan civilization. The enormity and complexity revealed by archaeological findings in Liangzhu culture, along with its fracture from the civilization of royal dynasties in Zhongyuan in the Bronze Age, does not support the linear evolutionary account, in which East Asian civilization progressed from small to big one-dimensionally. To fully grasp the details of the complicated origin and development of the state in East Asia calls for more archaeological fieldwork and integrative research in the future.

\section{Works Cited}

An Zhimin 安志敏. “Shi lun Huanghe liuyv xin shiqi shidai wenhua 試論黄河流域新石 器時代文化 [Neolithic Culture in the Yellow River Basin]." Kaogu 考古, no. 11 (1959): $559-65$.

Chang, Kwang-chih. The Archaeology of Ancient China. 4th ed. New Haven: Yale University Press, 1986.

Chang, Kwang-chih 張光直. "Zhongguo xianghu zuoyongquan yu wenming de xingcheng 中國相互作用圈與文明的形成 [The Mutually Influencing Circles and the Formation of Civilization]." In Qingzhu Su Bingqi kaogu wushiwunian lunwenji 慶祝蘇秉琦考古五十五年論文集 [A Collection of Essays in Celebration of Su Bingqi's 55-year Archaeological Work], 1-23. Beijing: Cultural Relics Publishing House, 1989.

Chen Xingcan 陳星燦. “Cong yiyuan dao duoyuan: Zhongguo wenming qiyuan yanjiu de xinlu licheng 從一元到多元: 中國文明起源研究的心路歷程 [From Monism to

25 Xu Hong, "Lianxu' zhong de 'duanlie'-Guanyu Zhongguo wenming yu zaoqi guojia xingcheng guocheng de sikao ‘連續’中的“斷裂”一關於中國文明與早期國家形成過 程的思考 [The 'Fracture' within 'Continuity': Reflections on the Chinese Civilization and the Formation of Early States]," Cultural Relics, no. 2 (2001). 
Pluralism: The Study of the Origin of the Chinese Civilization]." Zhongyuan wenwu 中原文物, no. 2 (2002): 6-9.

Engels, Friedrich 恩格斯. “Jiating, siyouzhi he guojia de qiyuan 家庭、私有制和國 家的起源 [The Origin of the Family, Private Property and the State].” In Makesi Engesi xuanji 馬克思恩格斯選集 [Marx and Engels Collected Works], vol. 4. Beijing: Renmin chubanshe, 1995 .

Henan sheng bowuguan 河南省博物館, Zhengzhou shi bowuguan 鄭州市博物 館. “Zhengzhou Shangdai cheng yizhi fajue baogao 鄭州商代城遺址發掘報告 [Excavation Report of Shang Relics in Zhengzhou]." In Wenwu ziliao congkan 文物 資料叢刊, vol. 1. Beijing: Wenwu chubanshe, 1977.

Henan sheng kaogu xuehui 河南省考古學會, Henan sheng bowuguan 河南省博物 館. Xia wenhua lunwen xuanji 夏文化論文選集 [Selected Papers on the Xia Culture]. Zhengzhou: Zhongzhou guji chubanshe, 1985.

Li Ji 李濟. Anyang-Yinshang gudu faxian fajue fuyuan ji 安陽: 殷商古都發現、發 掘、復原記 [Anyang: A Chronicle of the Discovery, Excavation, and Reconstruction of the Ancient Capital of the Shang Dynasty], trans. Su Xiuju 蘇秀菊 et al. Beijing: Zhongguo shehui kexue chubanshe, 1990.

Shi Xingbang 石興邦. “Huanghe liuyu yuanshi shehui kaogu yanjiu shang de ruogan wenti” 黃河流域原始社會考古研究上的若干問題 [Archaeological Problems of Primitive Societies in the Yellow River Basin].” Kao Gu 考古 [Archaeology], no. 10 (1959): 566-70.

Su Bingqi 蘇秉琦. Huaren-Long de chuanren-Zhongguoren-Kaogu xungen ji 華人. 龍的傳人.中國人一考古尋根記 [Ethnic Chinese, Descendants of the Dragon, the Chinese People: In Search of an Archaeological Root]. Shenyang: Liaoning daxue chubanshe, 1994.

Su Bingqi 蘇秉琦. Zhongguo wenming qiyuan xintan 中國文明起源新探 $[A \mathrm{New}$ Investigation into the Origin of the Chinese Civilization]. Shanghai: Sanlian shudian, 1999.

Su Bingqi 蘇秉琦 and Yin Weizhang 殷瑋璋. “Guanyu kaogu wenhua de quxi leixing wenti 關於考古學文化的區系類型問題 [Archaeological Culture: Region, System, Class]." Wenwu 文物, no. 5 (1981): 10-17.

Tang Lan 唐蘭. “Zhongguo you liuqian duo nian de wenmingshi-Lun Dawenkou wenhua shi Shaohao wenhua 中國有六千多年的文明史一論大汶口文化是少昊文化 [China Has Over 6000 Years of Civilized History: On How the Dawenkou Culture Is Shaohao Culture]." In Dagongbao zai Gang fukan 30 zhounian jinian wenji 大公報在 港復刊 30 週年紀念文集 [Collected Papers for the 3oth Anniversary of the Resuming Publication of Ta Kung Pao], 23-58. Hong Kong: Dagongbao, 1978.

Tang Lan 唐蘭. "Zhongguo nuli zhi shehui de shangxian yuan zai wu, liu qian nian qian-lun xin faxian de Dawenkou wenhua yu taoqi wenzi 中國奴隸制社會的上 限遠在五、六千年前一論新發現的大汶口文化與其陶器文字 [The Upper Limit 
of the Chinese Slavery Society Is 5000-6,00o Years Ago: On the New Discovery of the Dawenkou Culture and Its Pottery Scripts]." In Dawenkou wenhua taolun wenji 大汶口文化討論文集 [Collected Essays on the Dawenkou Culture], 120-46. Jinan: Qilu shushe, 1981.

Trigger, Bruce G. 布魯斯 - 炊格爾. Shijian yu chuantong 時間與傳統 [Time and Traditions], trans. Jiang Zudi 蔣祖棣, and Liu Ying 劉英. Shanghai: Sanlian shudian, 1991.

Wang Guowei 王國維. Guantang jilin 觀堂集林 [Guantang's Selected Works], part I, vol. 9. Beijing: Zhonghua shuju, 1959.

Xia-Shang-Zhou duandai gongcheng zhuanjia zu 夏商周斷代工程專家組. XiaShang-Zhou duandai gongcheng 1996-200o nian jieduan chengguo baogao jianben 夏商周斷代工程 1996-2000 年階段成果報告（簡本）[The Xia-Shang-Zhou Chronology Project Report for the years 1996-200o (abridged)]. Beijing: Shijie tushu chuban gongsi, 2000.

$\mathrm{Xu}$ Hong 許宏. Zuizao de Zhongguo 最早的中國 [The Earliest China]. Beijing: Kexue chubanshe, 2009 .

Xu Hong 許宏. Heyi Zhongguo: Gongyuan qian 2000 nian de Zhongyuan tujing 何以中 國-西元前 2000 年的中原圖景 [Why Is It China: The Zhongyuan Landscape in 2000 $B C E]$. Shanghai: Sanlian shudian, 2014.

$\mathrm{Xu}$ Hong 許宏. “'Lianxu' zhong de 'duanlie'—Guanyu Zhongguo wenming yu zaoqi guojia xingcheng guocheng de sikao ‘連續” 中的 “斷裂” 一關於中國文明與 早期國家形成過程的思考 [The 'Fracture' within 'Continuity': Reflections on the Chinese Civilization and the Formation of Early States].” Wen Wu 文物, no. 2 (2001): 86-91.

Xu Hong 許宏. “Fangfalun shijiao xia de Xia Shang fenjie yanjiu 方法論視角下的夏商 分界研究 [The Methodological Demarcation of Xia from Shang]." In Sandai kaogu 三代考古 [Archaeology of Three Dynasties], no. 3, 68-80. Beijing: Kexue chubanshe, 2009.

Xu Hong 許宏. “Xin Zhongyuan zhongxin lun de xueshushi jiexi ‘新中原中心論” 的 學術史解析 [An Analysis of the History of 'Neo-Zhongyuan-centrism'].” In Wuxian youyou yuanguqing — Tong Zhuchen xiansheng jinian wenji 無限悠悠遠古情一冬柱 臣先生紀念文集 [Collected Essays in Memory of Tong Zhuchen]. Beijing: Kexue chubanshe, 2014.

Xu Xusheng 徐旭生. “1959 nian xia Yuxi diaocha Xiaxu de chubu baogao 1959 年夏豫西 調查 ‘夏墟” 的初步報告 [Preliminary Report of the Investigations into 'Xiaxu' in Western Henan in the Summer of 1959]." Kaogu 考古, no. 11 (1959): 592-6oo.

Yan Wenming 嚴文明. "Zhongguo shiqian wenhua de tongyixing yu duoyangxing 中國史前文化的統一性與多樣性 [The Unity and Diversity in Chinese Prehistoric Culture].” Wen Wu 文物, no. 3 (1987): 38-50.

Zhang Xuehai 張學海. “Xin Zhongyuan zhongxin lun 新中原中心論 [Neo-ZhongyuanCentrism]." Zhongyuan wenwu 中原文物, no. 3 (2002): 7-12. 
Zhao Hui 趙輝. “Yi Zhongyuan wei zhongxin de lishi qushi de xingcheng 以中原為中 心的歷史趨勢的形成 [The Formation of the Zhongyuan-centric Historical Trend].” Wen Wu 文物, no. 1 (2000): 41-47.

Zhao Hui 趙輝. “Zhongguo de shiqian jichu—zai lun yi Zhongyuan wei zhongxin de lishi qushi 中國的史前基礎一再論以中原為中心的歷史趨勢 [The Prehistoric Foundation of China: Revisiting the Zhongyuan-centric Historical Trend]." Wen Wu 文物, no. 8 (2006): 50-54.

Zheng Jiexiang 鄭傑祥, ed. Xia wenhua lunji 夏文化論集 [An Anthology of the Xia Culture]. Beijing: Wenwu chubanshe, 2002.

Zhongguo shehui kexueyuan kaogu yanjiusuo 中國社會科學院考古研究所, Zhongguo shehui kexueyuan gudai wenming yanjiu zhongxin 中國社會科學院古代文明 研究中心, ed. Zhongguo wenming qiyuan yanjiu yaolan 中國文明起源研究要覽 [A Survey of the Studies on the Origin of the Chinese Civilization]. Beijing: Wenwu chubanshe, 2003 .

Zhongguo xianqin shi xuehui 中國先秦史學會, ed. Xia shi luncong 夏史論叢 [Collected Essays on the History of Xia]. Jinan: Qilu shushe, 1985.

Zhu Naicheng 朱乃誠. Zhongguo wenming qiyuan yanjiu 中國文明起源研究 [A Study of the Origin of the Chinese Civilization]. Fuzhou: Fujian renmin chubanshe, 2006.

Zou Heng 鄒衡. “Shi lun Zhengzhou xin faxian de Yin Shang wenhua yizhi 試論 鄭州新發現的殷商文化遺址 [The New Discovery of Yin-Shang Cultural Site in Zhengzhou]." Kaogu xuebao 考古學報, no. 3 (1956): 77-103. 